\title{
Neutron Activation Analysis in Tobacco and Cigarette Smoke Studies: 2R1 Cigarette Composition, Smoke Transference and Butt Filtration*
}

\author{
by
}

R. W. Jenkins, Jr.

Pbilip Morris Research Center, Richmond, Virginia, U.S.A.

and

C. Goldey and T. G. Williamson

Department of Nuclear Engineering, University of Virginia, Charlottesville, Virginia, U.S.A.

\section{SUMMARY}

Presented are the results from the use of neutron activation analyses to determine some of the inorganic components of the complete 2R1 reference cigarette, the tobacco filler, the cigarette paper, the dropped ash and the mainstream particulate smoke. Transference values are given for $\mathrm{Na}, \mathrm{K}, \mathrm{Br}, \mathrm{Cl}, \mathrm{Co}, \mathrm{Rb}, \mathrm{Al}, \mathrm{Sc}$ and Mn.

Neutron activation analyses were used to determine butt filtration of selected inorganics in the tobacco rod and in cellulose acetate filters. Butt filtration curves for each $5 \mathrm{~mm}$ section behind the cigarette coal were constructed from the data. $\mathrm{Na}, \mathrm{K}, \mathrm{Br}$ and $\mathrm{Cl}$ appeared to be removed by normal filtration mechanisms (direct impaction, interception, or diffusion) of entrained particles of inorganic residue coming from the cigarette coal. Vapor condensation of the inorganics studied was not considered a major filtration mechanism because a uniform filtration was observed at distances far enough behind the coal that the smoke would have been at room temperature with essentially all condensation completed.

\footnotetext{
* Received: 17th March 1983 - accepted: 3rd September 1985.
}

Calcium and magnesium were shown to be removed in such a manner as to indicate a removal mechanism dependent on very large particles enriched in these elements. A proposed mechanism is given to account for the lack of any detectable transference of these elements to mainstream smoke.

\section{ZUSAMMENFASSUNG}

Die vollständige Versuchszigarette $2 \mathrm{R} 1$, deren $T 2$ bakfüllung, Zigarettenpapier, die nach dem Verrauchen verbleibende Asche und die Partikelphase des. Hauptstromrauches wurden unter Einsatz von Neutronenaktivierung auf den Gehalt an einigen anorganischen Verbindungen untersucht. Über den Rauchübergang folgender Substanzen wird berichtet: $\mathrm{Na}, \mathrm{K}, \mathrm{Br}, \mathrm{Cl}$, $\mathrm{Co}, \mathrm{Rb}, \mathrm{Al}, \mathrm{Sc}$ und $\mathrm{Mn}$.

Mit Hilfe der Neutronenaktivierung wurde bestimmt, in welchem $\mathrm{MaBe}$ einzelne anorganische Verbindungen im Tabakstrang und im Celluloseacetatfilter selektiv retiniert werden. Auf der Basis der beobachteten Werte wurden für den gesamten hinter der Glutzone befindlichen Bereich der Zigarette in Abschnitten von jeweils 
$5 \mathrm{~mm}$ Retentionskurven erstellt. Die Retention von $\mathrm{Na}$, $\mathrm{K}, \mathrm{Br}$ und $\mathrm{Cl}$ scheint auf gewöhnlichen Filtrationsmechanismen (direkte Impaktion bzw. Abfangen oder Diffusion) zu beruhen, Eine Retention der Substanzen durch Kondensation der Gasphase des Rauches spielt nach Meinung der Autoren keine größere Rolle, da eine einheitliche Filtration in Entfernungen von der Glutzone beobachtet wurde, die so groß waren, daß der Rauch auf Zimmertemperatur abgekühlt und die Kondensation abgeschlossen sein dürfte.

Die Entfernung von Calcium und Magnesium entspricht der sehr großer Partikel, die diese Elemente offensichtlich anreichern. Für die Tatsache, daß beide Elemente im Hauptstromrauch gar nicht auffindbar sind, wird ein Mechanismus vorgeschlagen.

\section{RESUME}

Cette étude présente les résultats d'analyses par activation neutronique réalisées en vue de déterminer les quantités respectives de quelques-unes des substances minérales contenues dans la cigarette de référence $2 R 1$ complète, le tabac de remplissage, le papier a cigarettes, les cendres produites et la phase particulaire de la fumée du courant principal Elle a porté sur le passage dans la fumée des éléments suivants: $\mathrm{Na}, \mathrm{K}, \mathrm{Br}, \mathrm{Cl}, \mathrm{Co}, \mathrm{Rb}, \mathrm{Al}$, Sc et $\mathrm{Mn}$.

L'activation neutronique a permis de déterminer dans quelle mesure certains composés minéraux pouvaient être retenus de façon sélective dans le boudin de tabac et dans le filtre en acétate de cellulose. Sur la base des valeurs trouvées, on a établi des courbes de rétention pour l'ensemble de la partie de la cigarette se trouvant à l'arrière de la zone incandescente, et ce, en considérant des tronçons successifs de $5 \mathrm{~mm}$ de longueur. La rétention de $\mathrm{Na}, \mathrm{K}$, $\mathrm{Br}$ et $\mathrm{Cl}$ semble être due à des mécanismes de filtration habituels (impact direct / interception ou diffusion). Selon les auteurs, la rétention des substances par condensation de la phase gazeuse de la fumée ne joue pas ici de rôle important, car on observe une filtration uniforme à des distances de la zone incandescente suffisamment grandes pour que l'on puisse supposer que la fumée avait été refroidie à la température ambiante et que la condensation était terminée.

L'élimination du calcium et du magnésium correspond aux très grosses particules qui sont manifestement riches en ces éléments. Un mécanisme est proposé par les auteurs pour expliquer le fait que ces deux éléments ne puissent être décelés dans la fumée du courant principal.

\section{INTRODUCTION}

Tobacco and tobacco smoke are good subjects for instrumental neutron activation analyses (NAA) since over 20 elements can be detected with a combination of short and long neutron irradiations. The literature contains many references to analyses done on various blends and on tobacco grown worldwide. A subject of popular study has been the University of Kentucky reference cigarette coded the $1 R 1$ and fabricated in 1969. This cigarette was investigated by the use of NAA by Nadkarni et al. (1) who reported 28 elements and by Jenkins and Williamson (2) who reported 21 elements.

In 1973, another University of Kentucky reference cigarette, $2 R 1$, was fabricated as a replacement for the $1 R 1$ cigarette. To date, very little has been published on the elemental composition of the $2 \mathrm{R} 1$. This report is on the determination of 15 elements in the $2 R 1$ cigarette. Studies of the removal of some of these elements by the cigarette butt provide some insight as to the mechanisms of transfer into the mainstream smoke.

\section{EXPERIMENTAL METHODS}

\section{Cigarette for Neutron Activation Analyses (NAA)}

The machine-made cigarettes utilized in this study were the reference cigarettes developed by the Tobacco and Health Research Program of the University of Kentucky, coded $1 R 1$ and $2 R 1$. These cigarettes were equilibrated at $24^{\circ} \mathrm{C}$ and $60 \%$ relative humidity prior to usage.

\section{Cigarette Neutron Irradiation}

Cigarettes or cigarette filters were individually heatsealed in polyethylene tubing of $9 \mathrm{~mm}$ inside diameter. The tubes containing the cigarettes or filters along with vials containing standard solutions of $\mathrm{NaCl}$ and $\mathrm{KBr}$ were placed inside a nylon rabbit irradiation vessel. The samples were irradiated in the University of Virginia 2-megawatt swimming pool reactor for ten minutes at a neutron flux of $3 \times 10^{13}$ neutrons $\mathrm{cm}^{-2} \mathrm{~s}^{-1}$. The standard salt solutions provided accurate dosimetry of the neutron flux for each exposure. After the irradiation, the tubes were immediately opened and placed into a lead storage pig for transport to the smoking machine.

\section{Cigarette Smoking}

The activated cigarettes were immediately transferred from the storage containers into a total smoke collection machine and smoked under standard conditions as previously described (8).

\section{Sample Gamma Radioactivity Measwrements}

The samples were counted directly on a $\mathrm{Ge}(\mathrm{L}, \mathrm{i})$ detector (Ortec) coupled to a preamplifier (Ortec) and in turn to a Tracor-Northern TN-11 computer based analyzer system with data output by teletype. Weighed aliquots of the butt, filter, or ash were placed in polyethylene counting vials and the concentrations measured with 
the $\mathrm{Ge}(\mathrm{Li})$ detector system. Standardization was by direct comparison to known activated $\mathrm{NaCl}$ and $\mathrm{KBr}$ solutions placed in the same geometrical configurations.

\section{RESULTS AND DISCUSSION}

In any experiment to determine the elemental transference from the cigarette to smoke, the smoke collection technique utilized is very important. Nadkarni (3) has utilized the collection of the smoke condensate in conventional cold traps, the removal of water by solvent extraction, and the subsequent sampling of this condensate for NAA. Errors in the amount of condensate per cigarette (several hundreds of cigarettes are normally used), the water content of the condensate, accurate sample weights and, perhaps most importantly, the homogeneity of the condensate, are limiting factors. Jenkins and Williamson (2) have used the technique of direct impaction of the smoke into the bottom of the sample irradiation vial; however, this technique offers no indication that a quantitative removal of the elements in question was achieved. Williamson and Jenkins (4) also reported the collection of the smoke on conventional Cambridge filters when the tobacco industry accepted CORESTA standard smoking conditions (one 2-second puff per minute, $35 \mathrm{ml}$ volume) were used. NAA on the filters containing the smoke were unacceptable due to high inorganic backgrounds present in the filters. Another technique was used in which the cigarette was first irradiated and then the labelled smoke was collected on the filter and counted directly. This technique overcame any background and/or contamination problems; but because of the low transference of many elements, these analyses were limited to only a few elements.

In this study, both the collection of the smoke by cold traps (defined as whole smoke condensate) and the filtration of the activated smoke by Cambridge filters were utilized. The results on the $2 \mathrm{R} 1$ cigarette are shown in Table 1. Data are reported for the filler, the cigarette paper, the complete cigarette, the dropped ash, and the whole smoke condensate. All data are expressed as micrograms per cigarette, with the condensate being that from smoking to a $23 \mathrm{~mm}$ butt length. The ash values are corrected to account for the ash that would result from the burning of an entire cigarette rod $(85 \mathrm{~mm})$. There have been attempts to measure delivery values by difference between total cigarette and ash

Table 1.

2R1 clgarette (micrograms per cigarette).

\begin{tabular}{ccccccc} 
& Tobacco & Paper & Clgarette & Ash & Condensate \\
\cline { 2 - 6 } Weight (g) & 1.1 & 0.05 & 1.15 & 0.17 & 0.033 \\
$\mathrm{Na}$ & $587 \pm 51$ & $11 \pm 1$ & $598 \pm 52$ & $546 \pm 36$ & $2.2 \pm 0.2$ \\
$\mathrm{Mg}$ & $5500 \pm 1600$ & $24 \pm 2$ & $5520 \pm 1600$ & $5800 \pm 500$ & n.d. \\
$\mathrm{Al}$ & $554 \pm 170$ & $2.4 \pm 0.4$ & $556 \pm 170$ & $570 \pm 70$ & $0.06 \pm 0.015$ \\
$\mathrm{Cl}$ & $7420 \pm 2200$ & $190 \pm 15$ & $7610 \pm 2200$ & $5840 \pm 120$ & $82 \pm 3$ \\
$\mathrm{~K}$ & $38100 \pm 5000$ & $190 \pm 23$ & $38300 \pm 5000$ & $30300 \pm 1200$ & $130 \pm 9$ \\
$\mathrm{Ca}$ & $22100 \pm 2900$ & $1020 \pm 50$ & $25000 \pm 2900$ & $32100 \pm 2000$ & n.d. \\
$\mathrm{Sc}$ & $0.10 \pm 0.03$ & $0.002 \pm 0.0005$ & $0.10 \pm 0.03$ & $0.16 \pm 0.03$ & $0.000027 \pm 0.000008$ \\
$\mathrm{Mn}$ & $139 \pm 35$ & $0.4 \pm 0.05$ & $139 \pm 35$ & $160 \pm 43$ & $0.006 \pm 0.002$ \\
$\mathrm{Fe}$ & $360 \pm 50$ & $9.5 \pm 2.3$ & $370 \pm 50$ & $390 \pm 50$ & n.d. \\
$\mathrm{Co}$ & $0.77 \pm 0.07$ & $0.028 \pm 0.003$ & $0.80 \pm 0.07$ & $0.80 \pm 0.40$ & $0.011 \pm 0.005$ \\
$\mathrm{Br}$ & $124 \pm 22$ & $2.0 \pm 0.2$ & $126 \pm 22$ & $99 \pm 8$ & $1.4 \pm 0.04$ \\
$\mathrm{Rb}$ & $14 \pm 4$ & n.d.* & $14 \pm 4$ & $16 \pm 1$ & $0.08 \pm 0.01$ \\
$\mathrm{La}$ & $2.0 \pm 0.3$ & $0.011 \pm 0.003$ & $2.0 \pm 0.3$ & $1.7 \pm 0.4$ & n.d. \\
$\mathrm{Ce}$ & $2.0 \pm 0.6$ & n.d. & $2.0 \pm 0.6$ & $2.2 \pm 0.6$ & n.d. \\
$\mathrm{Sm}$ & $0.19 \pm 0.03$ & $0.003 \pm 0.0002$ & $0.19 \pm 0.03$ & $0.16 \pm 0.03$ & n.d. \\
\hline
\end{tabular}

" not detected. 


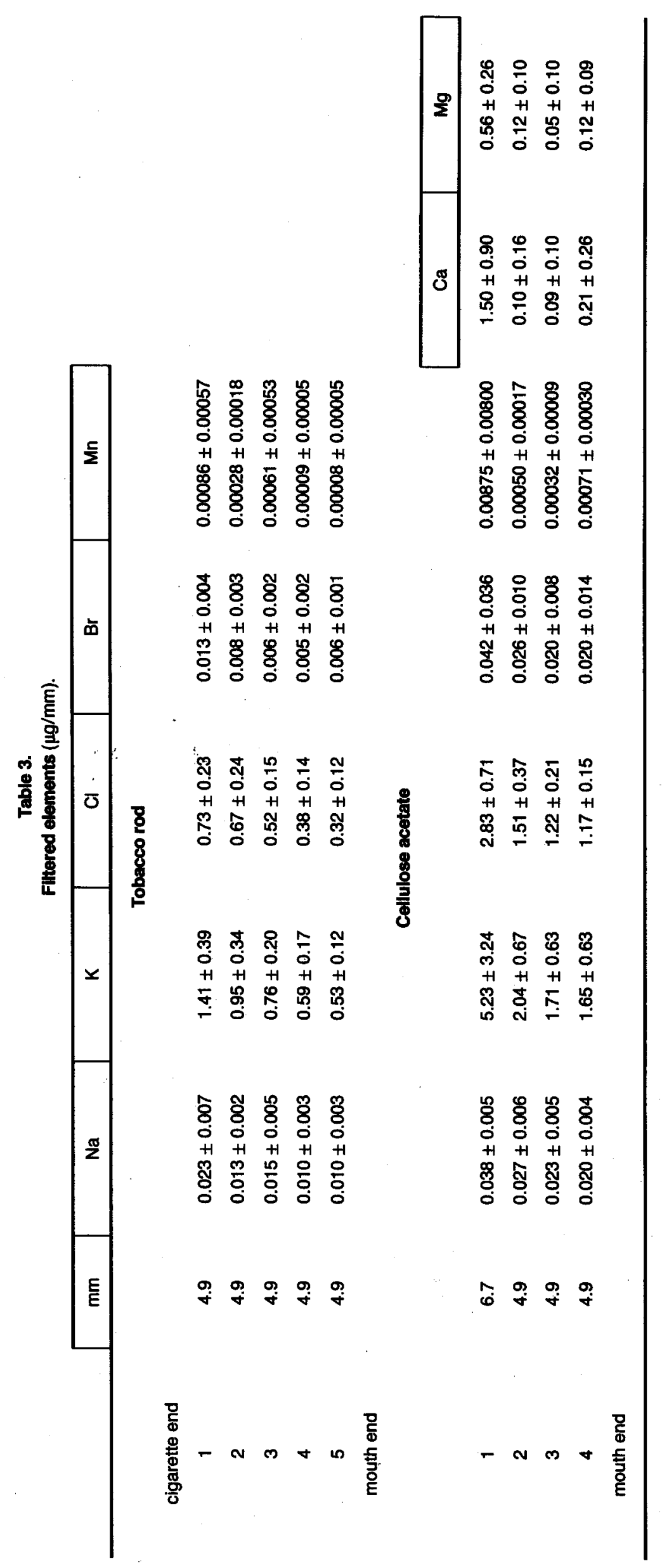


Table 2.

Percent dellvery to malnstream condensate (based on $33 \mathrm{mg}$ of dry condensate per cigarette and $73 \%$ of the cigarette consumed in smoking).

\begin{tabular}{lc|c|c|c}
\cline { 2 - 5 } & \multicolumn{2}{c|}{ 2R1 cigarette } & \multicolumn{2}{c}{ 1R1 cigarette } \\
\cline { 2 - 5 } & cold trap & $\begin{array}{c}\text { Cambridge } \\
\text { pad }\end{array}$ & cold trap & $\begin{array}{c}\text { Cambridge } \\
\text { pad }\end{array}$ \\
\hline $\mathrm{Cl}$ & 1.5 & 1.3 & 1.2 & 1.4 \\
$\mathrm{Br}$ & 1.5 & 0.89 & 1.5 & 1.2 \\
$\mathrm{Co}$ & 1.9 & - & - & - \\
$\mathrm{Rb}$ & 0.78 & - & 0.18 & - \\
$\mathrm{Na}$ & 0.50 & 0.31 & 0.25 & 0.29 \\
$\mathrm{~K}$ & 0.46 & 0.33 & 0.20 & 0.38 \\
$\mathrm{Al}$ & 0.014 & - & 0.009 & - \\
$\mathrm{Sc}$ & 0.037 & - & 0.018 & - \\
$\mathrm{Mn}$ & 0.006 & 0.006 & 0.004 & 0.003 \\
\hline
\end{tabular}

concentration. Because of the uncertainty in the measurement and the small amounts of material delivered, this approach is unacceptable.

In order to relate these values of delivery to past reference values, the data on the $2 \mathrm{R} 1$ cigarette are compared (Table 2) to previous data generated by the same techniques on the $1 \mathrm{R} 1$ cigarette, expressed as percent delivery from the amount of the cigarette that was consumed during smoking. When the factors such as collection techniques, errors in sampling, and the nonhomogeneous nature of the cigarette are considered, good agreement is obtained. From Table 2, the percent delivery to mainstream particulate matter can roughly be separated into three categories: first, chlorine, bromine and cobalt, for which the delivery is greater than $1 \%$; second, sodium, potassium and rubidium, for which the delivery is between $0.1 \%$ and $1 \%$; and third, manganese, scandium and aluminum for which the delivery is less than $0.1 \%$. Two omissions from the table are calcium and magnesium. Both are major constituents of tobacco, and can be found in tobacco by NAA, but neither can be found in the mainstream particulate phase at a sensitivity level of about $0.3 \mathrm{ppm}$ for calcium and $0.1 \mathrm{ppm}$ for magnesium. Cogbill and Hobbs (5), in a classic paper on constituents in mainstream smoke from commercial cigarettes, report less than 0.4 microgram of calcium in mainstream smoke and 0.07 microgram of magnesium, which corresponds to a percent transfer of 0.0001 . The analysis technique of NAA under the laboratory smoking conditions can only detect calcium and magnesium above the general levels reported by Cogbill and Hobbs (4).

The halogens are known to transfer to smoke both as ionic and organohalogen compounds (6). In a previous paper (6), the organohalogen content was shown to be at least $10.8 \%$ of the total chlorine and $13.3 \%$ of the total bromine present in the mainstream smoke total particulate matter (TPM). Therefore, some reduction in the transference of these elements must be applied in order to compare their ionic halide values. In previous studies (7), entrainment of the inorganic residue into mainstream smoke was shown to be a major factor in the total chemical concentration of sodium, potassium, chlorine, bromine and manganese. The relative ratios of these elements (compared to potassium) in the whole smoke condensate (Table 1) from this study are essentially the same as previously reported (7) on size-separated mainstream smoke, once again implying that entrainment may be a major mechanism of transfer of these elements $(\mathrm{Na}, \mathrm{K}, \mathrm{Cl}, \mathrm{Br}, \mathrm{Mn}$ ) into smoke. This raises the question of why calcium and magnesium are not transferred to smoke by the entrainment mechanism along with the other observed elements. One explanation is that there may be some type of selective filtration for calcium and magnesium taking place in the cigarette tobacco rod and/or filter (butt). Two experiments were conducted to see if indeed this was true. In one, the "hot rod" experiment, $30 \mathrm{~mm}$ of the tobacco column was removed from 2R1 cigarettes. The resultant $55 \mathrm{~mm}$ of tobacco in the original paper tube was irradiated in the nuclear reactor, activating the elements studied. Immediately, the cold tobacco was reinserted into the hollow butt end of the irradiated cigarettes with a cig-a-mat Mark ${ }^{\bullet}$ (Jenkins and Ott, Inc.) cigarette maker. The cigarette was immediately smoked to a $23 \mathrm{~mm}$ butt. The butt then contained the radioactive smoke that had been filtered. These butts were sectioned into approximately five equal pieces, weighed, and each was counted for radioactivity.

In the second experiment, a normal 2R1 cigarette was cut to $63 \mathrm{~mm}$ length and a $22 \mathrm{~mm}$ cellulose acetate filter attached to one end with conventional tipping paper. The cigarette was smoked to a $25 \mathrm{~mm}$ butt and extinguished. The filter was separated from the tobacco and the tipping paper, and then the filter was sectioned into approximately $5 \mathrm{~mm}$ lengths. These filter sections were then activated along with controls and blank filter pieces.

In both experiments, at least six replications were done, the data averaged, and one standard deviation calculated from the mean. One standard deviation, in many cases, is large partly because of the small amounts of material measured, but mainly because of the variability in the blended tobacco filler. The tobaccos were well mixed, but because of their different geographical origins, they still represented a heterogeneous mixture and hence the observed variability from cigarette to cigarette. Each cigarette was smoked in a reverse puff smoking machine (8) at the coresta standard conditions of a 2-second, $35 \mathrm{~cm}^{3}$ puff, one per minute.

Table 3 lists the results expressed as micrograms of each element per millimeter of rod length. Due to the short half-life of radioactive calcium and magnesium, these elements could only be seen in the activated cellulose acetate filters. The relatively long time utilized in preparing and smoking the cigarettes which had been activated, caused the loss of a good portion of the usable radioactivity due to isotope decay. Examination of these results (Table 3 ) shows a different rate of filtra- 
Table 4.

Slope of distributions in filter and tobacco rod.

\begin{tabular}{lc|c}
\cline { 2 - 3 } & Tobacco rod & $\begin{array}{c}\text { Cellulose acetate } \\
\text { filter }\end{array}$ \\
\hline $\mathrm{Na}$ & -0.048 & -0.041 \\
$\mathrm{~K}$ & -0.050 & -0.073 \\
$\mathrm{Cl}$ & -0.046 & -0.058 \\
$\mathrm{Br}$ & -0.041 & -0.048 \\
$\mathrm{Mn}$ & -0.041 & -0.163 \\
$\mathrm{Ca}$ & - & -0.12 \\
$\mathrm{Mg}$ & -0.041 & -0.11 \\
\hline
\end{tabular}

tion for the element manganese occurring in the tobacco rod and in the cellulose acetate filter. The filter has a higher number of fibers per unit volume than the tobacco column, and may be the cause for the different filtration behavior that is shown by manganese.

The data for the variation of the concentration of sodium, potassium, chlorine and bromine as a function of the length of the filter or the tobacco rod can be fit (with a high correlation coefficient) to a logarithmic decay equation. The slopes of the logarithmic changes in concentration are tabulated in Table 4. This trend would indicate that for these elements there is a predominate filtration mechanism occurring which removes the material uniformly. This uniform removal is normally characteristic of a direct interception, impaction or diffusion filtration mechanism taking place.

For calcium and magnesium, the rate of removal is different from that of the other elements, and the correlation coefficient much poorer. For these elements, the majority of the material is deposited in the cigarette rod section closest behind the coal. This indicates that at least one or two different filtration mechanisms might be responsible. One mechanism for the quick removal of calcium and magnesium in the first section might be condensation of volatile compounds of these elements as the hot gases impinge on the cooler tobacco or filter on their way out of the cigarette. Another mechanism which could also explain this fast removal would be that of direct impaction of large particles highly enriched in these elements. It is well known that the thermal gradient behind the coal is extremely sharp, dropping from over $900^{\circ} \mathrm{C}$ to $25^{\circ} \mathrm{C}$ in less than $10 \mathrm{~mm} .(9,10)$ The removal by vapor condensation of sodium, potassium, chlorine and bromine along a first order curve much beyond $10 \mathrm{~mm}$ behind the coal would not seem very logical because the smoke should be essentially at room temperature and condensation would have long since ceased.

Even with the large errors involved, it can be interpreted from Table 3 that chlorine, bromine, sodium, potassium and manganese are removed uniformly by the tobacco column while magnesium, manganese and calcium show an entirely different rate of removal by the cellulose acetate. These data imply that calcium, magnesium and some manganese may exist in particles of different sizes which are more efficiently removed by the larger number of fibers present in the cellulose acetate filters. In fact, there exists a difference of an order of magnitude in the removal of calcium; manganese and magnesium between the first and last filter sections, compared to sodium, potassium, chlorine and bromine which showed only a factor of two. The rapid removal by the filter of the calcium, magnesium, and some of the manganese may be due to either vapor condensation, or more probably to an efficient, rapid impaction mechanism brought on by enriched particles of larger average size. Uydess (11) has reported the presence of such large size particles on normal cigarette filler as the tobacco is heated. He has described results, by the use of microscopy and SEM/x-ray analyses on tobacco shreds that have been heated, which indicate that a migration to the leaf surface of salts rich in calcium, potassium, and magnesium takes place. Uydess also observed a change from the relative uniform concentration of the elements in unheated tobacco to the highly enriched particles in the heated rod. The calcium, potassium and magnesium migrate into crystals which $U y$ dess observed on the leaf surface as the tobacco becomes heated in the approaching thermal gradient. Their relatively large $(1-5 \mu \mathrm{m})$ particle size range $U y d e s s$ observed would minimize their mechanical entrainment into the smoke stream, and because of their relatively large size, any of these larger entrained particles would quickly be filtered by the tobacco column (or filter if the cigarette is smoked close to the filter). This would produce the filtration seen from these experiments.

Other elements present in these salt crystals would also undergo a similar removal. Any potassium transferring along with the $\mathrm{Ca}$ may be small in amount compared to that associated with the $\mathrm{Na}, \mathrm{Cl}$ and $\mathrm{Br}$ and would show only slight effects in the overall results. The net effect on their filtration removal curve would be dependent on the relative amount of each element's enrichment in the salt crystals vs. the amount present in the remaining inorganic residue of the coal.

In an attempt to verify this possible scenario, 2R1 cigarettes were smoked under CORESTA standard conditions on a conventional piston smoking machine and then, after the fifth puff, extinguished by immersion in liquid nitrogen. SEM/x-ray analyses on the partially pyrolyzed tobacco shreds (between the char and the unpyrolyzed tobacco) showed the existence on the surface of relatively large salt-like particles $(\sim 2-5 \mu \mathrm{m})$. These particles were highly enriched in calcium, potassium and magnesium. The existence of these particles did not answer the question as to whether they were filtered from the smoke, or were formed due to migration of the endogenous elements to the leaf surface followed by particle formation as described by Uydess (11). The observation of salt particles does not rule out their formation due to vaporization of volatile salt compounds and the subsequent condensation of these compounds on the cooler tobacco. This would produce a more uniform concentration of the salts on the shreds, some- 
what like that which normally exists (11). Our analytical techniques were not sensitive enough to see the small additional material condensed on the shreds. Upon heating, these salts may also migrate to form enriched particles, which would then be indistinguishable from those present from the endogenous materials or those filtered from smoke.

It is obvious from these initial experiments that more experimental data are needed before any definite conclusions can be made explaining the low transfer of calcium and magnesium to mainstream smoke.

\section{REFERENCES}

1. Nadkarni, R. A., W. D. Ehmann and D. Burdick: Investigations on the relative transference of trace elements from cigarette tobacco into smoke condensate; Tob. Sci. 14 (1970) 37-39.

2. Williamson, T. G., and R. W. Jenkins, Jr.: Neutron activation analysis in tobacco and cigarette smoke studies - Metals and argon; 5th Symp. Recent Dev. Activation Anal., Oxford, England, 1978.

3. Nadkarni, R. A., and G. H. Morrison: Multielement instrumental neutron activation analysis of biological materials; Anal. Chem. 45 (1973) 19571960.

4. Jenkins, R. W., Jr., R. H. Newman, R. M. Ikeda and $R$. D. Carpenter: The determination by neutron activation analysis of selected elements in cigarettes; Anal, Lett. 4 (1971) 451-457.

5. Cogbill, E. C., and M. E. Hobbs: Transfer of metallic constituents of cigarettes to the mainstream smoke; Tob. Sci. 1 (1957) 68-73.
6. Jenkins, R. W., Jr., R. H. Newman, G. L. Lester, A. F. Frisch and T. G. Williamson: Neutron activation analysis in tobacco and cigarette smoke studies The halogens; Beitr. Tabakforsch. Int. 11 (1982) 195-202.

7. Jenkins, R. W., Jr., B. W. Francis, H. Flachsbart, W. Ştöber, J. R. Tucci and T. G. Williamson: Selected inorganic composition of mainstream cigarette smoke as a function of aerodynamic particle size; J. Aerosol Sci. 13 (1982) 459-468.

8. Jenkins, R. W., Jr., M. K. Chavis, R. H. Newman and F. A. Morrell: The quantitative recovery of smoke from radioactively labeled cigarettes; Int. J. Appl. Radiat. Isot. 22 (1971) 691-697.

9. Egerton, A., K. Gugan and F. J. Weinberg: The mechanism of smouldering in cigarettes; Combust. Flame (London) 7 (1963) 63-78.

10. Baker, R. R.: Temperature distribution inside a burning cigarette; Nature 247 (1974) 405-406.

11. Uydess, I., and J. Bebbs: Thermal degradation of tobacco; SEM and X-ray dispersive analysis of heated tobaccos; 34th 'Tobacco Chemists' Research Conference, Richmond, Va., U.S.A., 1980.

\section{Addresses of authors:}

Robert W. Jenkins, Jr., Philip Morris Research Center,

P. O. Box 26583,

Richmond, Virginia, 23261, U.S.A.

Thomas G. Williamson,

Department of Nuclear Engineering,

University of Virginia,

Charlottesville, Virginia, 22901, U.S.A. 